Man and Nature

L'homme et la nature

\title{
J.M.R. Lenz and the Humanizing Role of Literature
}

\section{Norman R. Diffey}

Volume 9, 1990

URI : https://id.erudit.org/iderudit/1012613ar

DOI : https://doi.org/10.7202/1012613ar

Aller au sommaire du numéro

Éditeur(s)

Canadian Society for Eighteenth-Century Studies / Société canadienne d'étude du dix-huitième siècle

ISSN

0824-3298 (imprimé)

1927-8810 (numérique)

Découvrir la revue

Citer cet article

Diffey, N. R. (1990). J.M.R. Lenz and the Humanizing Role of Literature. Man and Nature / L'homme et la nature, 9, 109-117. https://doi.org/10.7202/1012613ar

Copyright (c) Canadian Society for Eighteenth-Century Studies / Sociéte canadienne d'étude du dix-huitième siècle, 1990
Ce document est protégé par la loi sur le droit d'auteur. L'utilisation des services d'Érudit (y compris la reproduction) est assujettie à sa politique d'utilisation que vous pouvez consulter en ligne.

https://apropos.erudit.org/fr/usagers/politique-dutilisation/ 


\section{J.M.R. Lenz and the Humanizing Role of Literature}

The name J.M.R. Lenz stands in a symbolic relationship with the Sturm und Drang. In life and work, his destiny was intimately linked to that of the movement in a way less true of his contemporaries. His provocative plays and theoretical writings sprang from a consuming commitment to the artistic and social ideals expressed in the remarkable eruption of the early seventeen-seventies; thereafter he wrote little of enduring worth. A spent force, he was to incur Goethe's uncharitable assessment as 'ein vorübergehendes Meteor' in the firmament of German literature. ${ }^{1}$ However much this judgment has proved mistaken in view of his subsequent influence, it nevertheless indicates the close identity of Lenz's work and its brief historical context.

Despite iconoclastic pretensions, Sturm und Drang tends not to stray far from some guiding assumptions of the Enlightenment. Foremost among these is the perfectability of society. From this ensues a belief in the duty, - one might call it a pedagogical responsibility - , on the part of society's intellectual elite, to work towards the attainment of such perfection, under the infallible guidance of reason and nature. In this the creative writer - the 'Dichter' - is subject to the same obligations. Literature is assigned a didactic function. Poetry, epics, fables, satires, - all are viewed as instruments of moral improvement, adequately evaluated in terms of explicit moral content.

Lenz's writings contain many hints of an ambivalent attitude towards literature in society. These sometimes suggest that, in contrast to the uncomplicated optimism of the Enlightenment, he was bothered by the question of the tenability of the writer's role. On this issue an important voice had spoken with its customary eloquence: that of JeanJacques Rousseau, whose Discours sur les Sciences et les Arts viewed the cultivation of the mind as a cause and symptom of the decline of civilization. The German Enlightenment either ignored Rousseau altogether or else adopted some of his ideas eclectically. However, the writers of Sturm und Drang paid him a degree of homage normally reserved for Shakespeare. ${ }^{2}$ Rousseau's views on nature, civilization and freedom they embraced with enthusiasm, usually on the basis of a most cursory 
reading of his works, but his condemnation of the pen was difficult to overlook, - even if he himself was one of its most outstanding wielders. Moreover, he also singled out their favorite medium, the theatre, for special censure in the Lettre à $M$. $D^{\prime}$ Alembert, which states that a play is far more likely to arouse dangerous emotions in honest bourgeois breasts than to purge them.

Lenz was a great admirer of Rousseau. He was, moreover, certainly aware of these attacks on literature and the arts. ${ }^{3}$ The most obvious echo of the D'Alembert letter occurs in Die Soldaten, where a military chaplain accuses the theatre of undermining the sanctity of family life, through alluring depictions of 'die gröbsten Verbrechen gegen die heiligsten Rechte der Väter und Familien ....' As if in confirmation, the heroine Marie allows herself to be seduced by an officer following a visit to the theatre. ${ }^{5}$ On close examination, however, we note that the poor girl has already succumbed to the charms of a corruptive society, namely the Strasbourg officer corps, before consenting to see the play in question. We are thus faced with the same 'chicken-egg' question as Rousseau himself (in his celebrated preface to La nouvelle Héloïse ${ }^{6}$ ): Does literature corrupt society, or are only those already corrupt drawn to novels and plays in the first place? Lenz seems to lean towards the latter diagnosis. One of his recurrent figures is the shallowminded individual for whom reading becomes a substitute for real life. ${ }^{7}$ Such characters invariably display some deficiency in their moral sensibility which sooner or later brings misfortune upon themselves and those around them.

Repeatedly in his writings Lenz assails that sacred cow of the Enlightenment, its faith in the primacy of books to bring about the desired changes in society. ${ }^{8}$ We recall that the heroes of the Sturm und Drang, the larger-than-life figures of Götz and Franz Moor, were men of action, not words. Faust in his search for a satisfying translation of the beginning of the fourth Gospel finally settles on the less than literal rendering: 'Im Anfang war die Tat!' The writer, seeking justification for his role, therefore starts out from a position of weakness, beset with self-doubts which are hardly relieved by thoughts of Plato. In order to wrest back his claim to equality with the real movers of society, the writer in his sphere of activity must emulate the doer in the realm of politics and history. The only way to do this is to demonstrate that he too through his labours can bring about a profound shift in the way society views its present condition and its potential for change. Modern hindsight enables us to identify such a shift as the beginnings of that programmatic approach to literature which went hand in hand with the emergence of realism. ${ }^{9}$ It subsequently gave rise to the literary activism of Young Germany, itself an ancestor of that social realism which still prevails in a sizable part of modern Germany. 
At this point we should consider the nature of the 'reality,' social and political, in the face of which a writer of Lenz's generation was to define his role. Its horizons were exceedingly narrow. Eighteenth century Germany was little more than a collection of villages, whose squires vied with their neighbours in such trappings as the number of uniformed retainers and, certainly, in their eagerness to adorn their households with the embellishments of an imported neo-classical aesthetic cult, the Rococo. Rightly or wrongly, Lenz chose to identify the latter with the highly respected Christoph Wieland. ${ }^{10}$ On the surface the charge is that of sensuality. ${ }^{11}$ However, the real danger of aestheticism in Lenz's view lies not so much in any threat it may pose to the moral character of the individual as in its ultimate irrevelance to the compelling issues of social and cultural reform. As Madland remarks: 'For Lenz, Wieland's middleof-the-road position, his refusal to regard the attainment of perfection as man's ultimate goal, and his emphasis on a moderate and practical enjoyment of life, constitute a philosophical copout. ${ }^{12}$ Here, Lenz is certainly on common ground with Rousseau, who saw the cultivation of the arts as endemic to an idle and valueless society, or to use the image of a much more recent writer, a form of spiritual slackness, like the bow that has lost its tension. ${ }^{13}$

The destruction of Wieland's reputation was a major political objective of Lenz's literary reformist movement. An expression used by both him and a contemporary, and which undoubtedly refers to this campaign, is that of having a dirty but necessary job to do. ${ }^{14}$ The deployment of the crudest literary satire in order to remove Wieland from his pedestal as arbiter of German letters was primarily a means of clearing the way for an alternative model of the writer's role. Lenz did not have to look very far to find such a model. It was already at hand, in the titanic example of Goethe. Lenz's literary and aesthetic response to Goethe's writings, - during the still adulatory days of Strasbourg, that is, - has, to my knowledge not been looked at for a long time and is probably overdue. I will refer here to one document among several. ${ }^{15}$ It presents us with a somewhat different Goethe than the detached Olympian of later years, one who, in Lenz's eyes at least, stands in a less than arm's length relationship with the society around him.

In 1775, in response to Nicolai's parody of Goethe's Werther, Die Freuden des jungen Werthers, Lenz wrote his epistolary defense, Briefe über die Moralität der Leiden des jungen Werthers. Nicolai typified a rationalist Enlightenment view of passion as an aspect of dissonance in society, arbitrary and unpredictable in its consequences, in permanent opposition to virtue and duty, which are seen as underpinning the social order. Literature provides two outstanding exponents of this view in the persons of Wolmar in Rousseau's Héloise and Albert in Goethe's novel, 
both extremists in the cause of moderation, so to speak. Nicolai's attempt to bring these two characters into still closer parallel by having Werther imitate St. Pierre's act of renunciation is cleverly associated by Lenz with the bastion of the Aufklärung, when he refers repeatedly to 'Albert aus Berlin. $^{16}$

In his defense of Werther, Lenz may well have chosen to present a defiant assertion of the supremacy of individual rights over the greater good of society. In fact he does no such thing. For him Werther is a 'moral' book. He proclaims its Moralität with as much pretended authority as Nicolai himself and other such didactic authors as Sulzer or Eschenburg. ${ }^{17}$ It soon becomes clear, however, that the word has undergone a change in definition. Morality is understood not in terms of author intention, expressed in specific injunctions to this or that line of conduct, but rather in terms of moral effect. 'Warum legt man dem Dichter doch immer moralische Endzwecke unter, an die er nie gedacht hat. ${ }^{18}$ (This is the context of the often quoted passage in which Lenz expresses his irritation with those critics seeking the 'message' of Der Hofmeister. $)^{19}$ Thus at the end of the third of the Werther letters, the point at which the discussion effectively begins, Lenz declares: 'Laßt uns also einmal die Moralität dieses Romans untersuchen, nicht den moralischen Endzweck den sich der Dichter vorgesetzt (denn da hört er auf Dichter zu sein) sondern die moralische Wirkung die das Lesen dieses Romans auf die Herzen des Publikums haben könne und haben müsse. ${ }^{20}$ To understand the kind of effect he has in mind, we must be able to relate this to the particular 'public' which is its intended beneficiary.

I have already referred in general terms to the kind of society which for Lenz constituted the 'public.' The cramped and cramping world of contemporary Germany is the context he has in mind and he describes it with considerable distaste. In particular the women are viewed as artificial creatures. They are alienated from nature (their own and that around them), just like the women in Lenz's own plays, in fact. By contrast, Goethe's heroine, Lotte, is an example for 'jede Tochter Germaniens. ${ }^{21}$ In order to reform such a frigid and rigid society, - and here we are getting to the nub of the discussion, - the last thing one would wish to do would be to suppress the passions. On that view the most advanced society would be that of the Turks which, with its high degree of moral constraint, is certainly the most peaceful. ${ }^{22}$ Lenz is particularly derisive towards the notion that the young men will be tempted to imitate Werther's actions. To do so they would first have to identify with him, to feel what he has felt. It is precisely the incapacity for such empathy which lies at the root of Lenz's moral indictment of his society's ethos, what he calls its 'Sitten.' In the most spirited condemnation of that ethos, Lenz addresses the question of Goethe's alleged plagiarism, 
whether or not Werther is an imitation of Rousseau's Héloise. The passage in question is remarkable for its unusual sociological perspective and its moral relativism. We are told that Rousseau was writing consciously for a nation whose 'Sitten' were already corrupt. From a moralist viewpoint the French had nowhere to go but forward, so that for them the real value of the Héloise is indeed didactic: its reassertion of the marriage bond and Julie's renunciation of St. Preux. But in the case of Goethe, the target audience is quite different, and so is the 'moral effect' it is deemed to require. The passage is worth quoting at length:

Goethe der für steife Sitten schrieb wenn ich so sagen mag, wo man ein ewiges Gerede von Pflichten und Moral hört und nirgends Kraft und Leben spürt, nirgends Ausübung dessen was man hundertmal demonstriert hat und immer wieder von neuem demonstriert, wo man in den eisernen Fesseln einer altfränkischen Etikette alle seine edelsten Wünsche und Neigungen in den berauchten Wänden seiner Studierstube vorsichtig ersticken läßt und so bald sie sich melden, irgend ein System der Moral dagegen schreibt, oder in neuern Zeiten jämmerlich süßtönende tönendetönendetönendeKlagen, Idyllen und Romanzen und Spaziergänge und daß des Dings kein Ende ist - für Sitten wo Furchtsamkeit, Ernst und Pedanterei unsere Gesellschaften stimmen und insgeheim doch die verbotene Lust zehnmal rasender wütet, wo jenachdem denn nun endlich die elendeste Karikatur ausartet, die Herren nicht wissen was sie sagen, noch die Damen was sie antworten sollen, der Magister es nur für seine Schuldigkeit hält verliebt zu sein ohne daß er weiß in wen noch wie er's anzufangen habe, das arme Mädchen noch immer in ihrem süßen enenenalten Wahn jeden der sich ihr zuerst mit einem schönen Wörtchen nähert für einen Freier hält und sich hernach über die Untreue des Bösewichts zu Tode grämt der im Grunde sich nur im Kurtesieren bei ihr üben wollte - für diese drolligte Sitten, wo niemand Herz hat und wer noch eins hat nicht weiß was er damit anfangen soll - Goethe stellte einen jungen mutigen lebenvollen Helden auf die Bühne, der weiß was er will und wo er hinauswill, der den Tod selbst nicht scheut, wenn er ihn nur auf guten Wegen übereilt, der im Stande ist sich selbst zu strafen wenn er es wo versehen haben sollte. O guter edler Jüngling, heiliger Werther! könnte ich jemals nur den Schatten deines Werts mir eigen machen. ${ }^{23}$

Lenz's cultural pessimism springs from a perception of his society's profound spiritual malady, its suppression of all feeling. The substance of his complaint is repeated elsewhere in his characterization of Wieland: 'Er hat ... auf einer Seite unserer vaterländischen alten Steifigkeit, Langsamkeit und Pedanterei. . . . ${ }^{24}$ The role of literature, here ordained by the diagnosed needs of a given, rather than an ideal, audience, thus becomes clear. The author's function is essentially remedial, namely to reunite his public with those inner wells of feeling from which the forms 
of society have alienated it. In the same semantic field as 'Gefühl' we find 'Sensationen' and 'Empfindungen,' which are roughly synonomous and have as their referent an altogether nobler emotion than mere 'sensations.' Their negative counterpart is 'Enthusiasmus,' used by Werther's opponents to convey that unhealthy excess of emotion they considered 'gefährlich.' To these detractors, who consider Werther to be a moral threat, Lenz replies that: 'Ein Mensch der für das echte Gefühl alles dessen was Schön Groß Edel in der Natur oder in den Künsten abgestorben ist, bleibt in meinen Augen immer ein gefährlicher Mensch, schein' er auch so fromm und zahm als er wolle. ${ }^{25}$ Virtue as an outcome of restraint, mere piety, conflicts with Lenz's ideal of virtue as inner nobility expressed through action. ${ }^{26}$ Implied is an inspirational process which begins in those affective recesses of our being which, both in the Werther letters and in the Anmerkungen übers Theater, are 'felt darkly. ${ }^{27}$ The expression suggests forms of a potential other existence ultimately made manifest to the seeker, in St. Paul's sense when he speaks of seeing 'in a glass darkly.'

If the moral effect achieved through great literature thus begins deep within the individual through a resensitization of feeling, ultimately it is society, the collectivity, which will change. It becomes incumbent upon the theatre, as well as the novel, to reach and move its audience, to present it with visions of society's true potential and to stir the mind and spirit to will reform. Stated simply, literature's role is to serve humanity. Of this there can be no question in Lenz's mind, since the greatest of them all had done precisely that. Who, he asks, in the Anmerkungen übers Theater, can read Shakespeare's Julius Caesar and not sense 'die Würde menschlicher Natur' swelling in his breast, enabling him to feel 'den ganzen Umfang des Worts: Mensch?' ${ }^{28}$ Shakespeare himself is endowed elsewhere with the highest epithet, that of 'Mensch' - man, an embodiment of humanity - who, '... in jedem Verhältnis gleich bewandert, gleich stark, schlug ... ein Theater fürs ganze menschliche Geschlecht auf, wo jeder stehn, staunen, sich freuen, sich wiederfinden konnte, vom obersten bis zum untersten. ${ }^{29}$ Only by identifying with humanity can the writer justify his calling whereas Wieland's accolades derive from an effortless complacency, amounting to mere 'Aufgeben aller Rechte der Menschheit, Zusammenlegen der Hände in den Schoß.... . ${ }^{30}$

Stated thus, Lenz's understanding of the writer's mission is, true to the idealism of the time, universal in scope, optimistic in doctrine. Yet when related to the given reality of his society and his audience he finds himself inevitably forced back upon a mood of disillusionment, the relativist fears that great literature is unachievable without a noble readership. The paucity of feeling he saw everywhere around him, a 
degree of inner impoverishment which, paradoxically, made German society immune to Rousseau's 'corruptibilité,' surely made him doubt his own ability to harness his literary talents to the great task of humanizing his nation's 'Sitten.' This, I believe, accounts for the fragmentary nature of Lenz's work and the sense of a failed mission to which his letters sometimes refer. ${ }^{31}$

By the end of the eighteenth century, German letters had indeed come to espouse a truly noble ideal of humanity and the directions in which it might find perfection. Yet these led away from contemporary political and social realities: inwards to the ethical and aesthetical autonomy of the 'schöne Seele' - and backwards to the sunny land of Greece.

\section{NORMAN R. DIFFEY \\ University of Windsor}

\section{Notes}

1 'A passing meteor.' See Dichtung und Wahrheit, in J.W. v. Goethe, Gedenkausgabe der Werke, Briefe und Gespräche, ed. Ernst Beutler (Zurich: Artemis 1948 ff), X, 659.

2 For a review of the critical reception of Rousseau in Germany from the Aufklärung to the Sturm und Drang see, for example, this writer: N.R. Diffey, Jakob Michael Reinhold Lenz and Jean-Jacques Rousseau (Bonn: Bouvier, 1981), pp.26-46.

3 See, for example, the reference to Rousseau's rejection of the arts in the literary satire Pandämonium Germanicum ('Ich wünschte denn lieber mit Rousseau wir hätten gar keine und kröchen auf allen Vieren herum'). Jakob Michael Reinhold Lenz, Werke und Schriften, ed. Britta Titel und Helmut Haug, 2 vols. (Stuttgart: Goverts, 1966), II, 260.

4 'the ugliest crimes against the most sacred rights of parents and families.' Ibid., p. 193.

5 The better known version of the heroine's name is used here, although the Goverts edition, following the MS, calls her Mariane.

6 'Jamais fille chaste n'a lu de romans, et j'ai mis a celui-ci un titre assez decidé pour qu'en l'ouvrant on sût a quoi s'en tenir. Celle qui, malgré ce titre, en osera lire une seule page est une fille perdue; mais qu'elle n'impute point sa perte à ce livre, le mal Aetait fait d'avance': J.-J. Rousseau, Julie, ou la Nouvelle Héloïse (Paris: Garnier, 1960), p. 4.

7 Besides Marie, who made the mistake of reading Richardson's Pamela, other examples are Fritz and Gustchen in Der Hofmeister, Albertine in Der Landprediger and Hortensie in Zerbin, who only emerged from her studies at meal-times. 
8 Da es heutzutage mehr Leute gibt die Bücher schreiben, als die welche lesen und die letzteren gemeinlich weiser und verständiger sind als die ersten ...' Werke und Schriften, I, 254.

9 Recognition of Lenz's importance in the vanguard of German realism tended to be tentative and hesitant as long as literary historians took their terms of reference from the Goethezeit. The question is squarely addressed by H.-G. Schwarz in Dasein und Realität: Theorie und Praxis des Realismus bei J.M.R. Lenz (Bonn: Bouvier, 1985).

10 A useful and balanced analysis of Lenz's attitude towards Wieland is that of Helga Madland, 'Lenz and Wieland: The Dialectics of Friendship and Morality,' Lessing Yearbook, XVIII (1986), 197-208

11 The phrase used to describe this artistic failing is 'schlüpfriger Naturalismus.'

12 Op. cit., 201

13 Allan Bloom, The Closing of the American Mind (New York: Simon and Schuster, 1987), p. 51. The image is derived from Nietzsche, whose cultural pessimism is similar in mood to Rousseau's at this point.

14 See Werke und Schriften, I, 424 (footnote), also Justus Möser: 'Auch die Klinger, die Lenze und die Wagner zeigten in einzelnen Theilen eine Stärke wie Herkules, ob sie sich gleich auch, wie dieser, zuerst mit einer schmutzigen Arbeit beschäftigten, und vielleicht zu früh für deutsche Kunst und ihren Ruhm verstarben.' In Patriotische Phantasien (1774-78), IV. Quoted by Hans Wolff, 'Rousseau, Möser und der Kampf gegen das Rokoko,' Monatshefte, XXXIV (1942), 125.

15 For example, Uber Götz von Berlichingen complements some of the ideas of the Anmerkungen übers Theater.

16 Werke und Schriften, I, 390-91.

17 See M. Sommerfeld, 'Jakob Michael Reinhold Lenz und Goethes Werther auf Grund der neu aufgefundenen Lenzschen Briefe über die Moralität der Leiden des jungen Werthers,' Euphorion, XXIV (1922), 79.

18 'Why is one for ever attributing moral purposes to the writer, which he never thought cf?' Werke und Schriften, I, 384.

19 'Man hat mir allerlei moralische Endzwecke und philosophische Sätze bei einigen meiner Komödien angedichtet, ...': Ibid., p. 385.

20 'Let us examine the morality of this novel, not the moral purpose which the author may have set himself (for at that point he ceases to be an author), but the moral effect which the reading of this novel may and must have on the hearts of the public': Ibid., p. 386.

21 Ibid., p. 389.

22 'Nach dieser Proportion wären die Sitten der Türken die weisesten, weil sie die ruhigsten sind': Ibid., p. 393.

23 'Goethe, who was writing for stiff traditions, if I can put it thus, whereby all we hear is eternal prattling about duty and morals without any inkling of energy or life, or any realization of what has been and continues to be demonstrated a hundred times, whereby the iron fetters of the old Frankish code of ethics bids us prudently smother all our noblest desires and aspirations between our smoky study walls and, the minute they are announced, write some moral system against them or else, more recently, excruciatingly sweetsounding laments, idylls, romances and promenades, there being no end to the business, - for traditions 
whereby timorousness, earnestness and pedantry set the tone of our relationships whilst, deep down, the forbidden instincts rage ten times more intensely, and if, by chance, the liberties of the French happen to take hold, everything degenerates into the most wretched caricature, so that the gentlemen don't know what to say nor the ladies what to reply, the scholar feels he has an obligation to fall in love, not knowing with whom nor how to set about it, the poor maiden, still possessed by the sweet fantasies of childhood, sees a suitor in whosoever first approaches her with a pretty word or two and for ever after grieves herself to death over the faithlessness of the villain who in reality had wanted only to practice his courtship techniques, - for these absurd traditions whereby no one possesses a heart or, possessing one, has no idea what to do with it, Goethe placed upon the stage a vital and courageous hero who knows what he wants and where he wishes to go, who does not even shun death if encountered on a road that is good, who has the capacity to chastise himself should he have strayed in any way. O good and noble youth, saintly Werther, if only I could take but the shadow of your worth and make it mine': Ibid., pp. 398-99.

24 'the old stiffness of our fatherland, its slowness and pedantry ...' $:$ Ibid., p. 425.

25 'A man who is dead to true feeling for all that is beautiful, great and noble in nature and in art remains in my eyes a dangerous being, let him be as pious and obedient as he will': Ibid., p. 383.

26 For my development of this idea, see N.R. Diffey, 'Lenz, Rousseau, and the Problem of Striving,' Seminar X (1974), 165-80.

27 'Eben darin besteht Werthers Verdienst, daß er uns mit Leidenschaften und Empfindungen bekannt macht, die jeder in sich dunkel fühlt, die er aber nicht mit Namen zu nennen weiß.' Werke und Schriften, I, 393. See also p. 341.

28 '.. the dignity of human nature . . . the full breadth of the word: mankind ...': Ibid., I, p. 356.

29 '. . who, equally at home and equally powerful in every station, raised up a theatre for the entire human race, before which each could stand, marvel, rejoice and rediscover himself, from the highest to the lowest': Ibid., p. 362.

30 '... the abandonment of all human rights and folding one's hands in one's lap': Ibid., p. 441.

31 Cf. Ottomar Rudolf, Jacob Michael Reinhold Lenz, Moralist und Aufklärer (Bad Homburg: Gehlen, 1970), p. 238: 'Die Menschen durch poetische Werke zu bessern, scheint ihm nun unausführbar.' 